\title{
Analisis Penggunaan Google Classroom Pada Masa Pandemi Covid - 19 Terhadap Efektivitas Pembelajaran Mahasiswa
}

\author{
Hari Wahyuni*1, Eni Erwantiningsih², Ratna Pudyaningsih ${ }^{3}$ \\ 1,2,3Universitas Merdeka Pasuruan \\ Pasuruan, Indonesia
}

\section{e-mail: yuniprasetya55@gmail.com¹, enierwanti@ymail.com². ratnahend@gmail.com ${ }^{3}$}

Riwayat Artikel
Tanggal diajukan:
2 Februari 2021
Tanggal diterima :
12 Juli 2021
Tanggal
dipublikasikan:
15 Desember
2021

Pengutipan: Hari, W., Eni, E. \& Ratna, $\mathrm{P}$ (2021). Analisis Penggunaan Google Classroom Pada Masa Pandemi

Covid-19

Terhadap

Efektivitas

Pembelajaran

Mahasiswa.

Jurnal Pendidikan Ekonomi Undiksha, 13(2), 253-267.

http://dx.doi.org/1 $0.23887 /$ ijpe.v13i 2.31732

\begin{abstract}
Abstrak
Pandemi Covid - 19 telah menyebabkan berbagai sektor mengalami kendala, salah satu sektor yang sangat terdampak yaitu dunia pendidikan. Pemerintah menerapkan kebijakan terkait pendidikan agar siswa belajar dari rumah dengan memanfaatkan fasilitas teknologi. Salah satunya Program Studi Manajemen, Fakultas Ekonomi, Universitas Merdeka, Pasuruan, harus mengubah sistem pembelajaran konvensional dengan pembelajaran online.Pembelajaran online yang dilaksanakan di Program Studi Manajemen dengan memanfaatkan aplikasi Google Classroom.Maka tujuan dari penelitian ini adalah untuk menganalisis penggunaan Google Classroom selama pandemi Covid -19 terhadap efektivitas belajar siswa.Berdasarkan hasil penelitian, persepsi kegunaan berpengaruh langsung terhadap penggunaan Google Classrooms, persepsi kenyamanan dan kualitas layanan juga berpengaruh langsung terhadap penggunaan Google Classroom, sementara minat pengguna tidak berpengaruh pada penggunaan Google Classroom.Pengaruh tidak langsung dari persepsi kegunaan terhadap keefektifan pembelajaran siswa melalui penggunaan Google Classroom tidak didukung, sedangkan persepsi kenyamanan, minat pengguna dan kualitas layanan terhadap keefektifan pembelajaran siswa melalui penggunaan Google Classroom didukung.

Kata Kunci: Google Classroom; Pandemi Covid-19; Efektifitas Pembelajaran.
\end{abstract}

\begin{abstract}
The Covid-19 pandemic has caused various sectors to experience obstacles, one of the sectors that has been greatly affected is the world of education. The government implements policies related to education so that students learn from home by utilizing technology facilities. One of them is the Management Study Program, Faculty of Economics, Merdeka University, Pasuruan, which must change the conventional learning system with online learning. Online learning carried out in the Management Study Program by utilizing the Google Classroom application. So the purpose of this study is to analyze the use of Google Classroom during the Covid-19 pandemic on the effectiveness of student learning. Based on the research results, perceived usefulness has a direct effect on the use of Google Classrooms, perceptions of comfort and service quality also directly affect the use of Google Classroom, while user interest has no effect on the use of Google Classroom. The indirect effect of perceived usefulness on the effectiveness of student learning through the use of Google Classroom is not supported, while perceptions of convenience, user interest and service quality on the effectiveness of student learning through the use of Google Classroom are supported.
\end{abstract}

Keywords : Google Classroom; Pandemic Corona Virus 19; Quality of Learning 


\section{PENDAHULUAN}

Situasi saat ini memperlihatkan seluruh negara di dunia digemparkan dengan adanya wabah penyakit virus corona atau covid 19 yang berasal dari Wuhan, Propinsi Hubei, China.Akibat penularan virus corona ini sangat cepat maka World Health Organization (WHO) menetapkan kejadian ini sebagai pandemi. Pada tanggal 11 Maret 2020 World Health Organization (WHO) telah mendeklarasikan kejadian ini sebagai pandemi global corona virus 19 (covid -19). Menurut Cucinotta \& Vanelli dalam (Idad Suhada et al., 2020).

Berdasarkan Surat Edaran Mendikbud No.4 Tahun 2020 tentang pelaksanaan kebijakan dan pendidikan dalam masa darurat penyebaran corona virus desease (covid-19) kementrian pendidikan memberikan kebijakan untuk belajar dari rumah dengan metode menggunakan sistem pembelajaran dalam jaringan (daring). Pandemi corona virus - 19 dapat berdampak pada efektifitas pembelajaran namun dengan dilakukanya pembelajaran secara daring dengan berbagai platform yang disediakan pemerintah harapanya kualitas pembelajaran tetap maksimal walaupun mereka belajar secara virtual.

Indonesia menerapkan social distance di segala aspek kehidupan termasuk dunia pendidikan. Oleh karena itu, pembelajaran daring dapat dikatakan menjadi satusatunya pilihan pembelajaran yang dapat dilakukan oleh pendidik untuk menigkatkan mutu pembelajaran di Indonesia (Syarifudin, 2020). Didukung kajian empiris (Windarti, 2020) penyebab covid-19 tidak hanya berdampak pada kesehatan dan ekonomi global. Namun itu mempengaruhi semua sektor, terutama di sektor pendidikan. Hal ini ditunjukan dari "Situs UNESCO yang menyatakan bahwa pandemi Corona ini mengancam 577 juta pelajar di dunia. Jumlah siswa yang berpotensi berisiko dari pendidikan pra-sekolah dasar hingga sekolah menengah adalah 577.305.660. Sedangkan jumlah siswa yang berpotensi berisiko dari pendidikan tinggi adalah 86.034.287 orang."

Pandemi virus corona (covid - 19) sangat berdampak terhadap seluruh tingkatan pendidikan di Indonesia.Salah satunya di Prodi Manajemen Universitas merdeka Pasuruan harus merubah sistem pembelajaran tatap muka (convensional) menjadi sistem pembelajaran dalam jaringan (daring).Pemanfaatan e-learning yang biasa dikembangkan saat ini adalah menggunakan LMS (Learning Management System). Prodi Manajemen Fakultas Ekonomi Universitas Merdeka Pasuruan memanfaatkan aplikasi Google Classroom sebagai solusi metode pembelajaran daring. Penggunaan Google Classroom diharapkan dapat memberikan kemudahan dan meningkatkan mutu pembelajaran serta pengajaran di prodi Manajemen selama pandemi covid-19. Sejalan dengan kajian empiris yang dilakukan Utami (2019) penggunaan Google Classroom dapat memberikan kemudahan kepada mahasiswa saat mengakses materi, tugas Selain itu, juga dimudahkan untuk memperoleh pengumuman yang diberikan oleh dosen secara cepat sehingga menjadi efektif dan efisien dari segi waktu serta meningkatkan hasil belajar

Metode pembelajaran dengan aplikasi Google Classroom sesungguhnya dirancang guna mempermudah interaksi dosen dan mahasiswa dalam dunia maya. Aplikasi ini memberikan kesempatan kepada para dosen untuk mengeksplorasi gagasan keilmuan yang dimilikinya kepada mahasiswa. Dosen memliki keleluasaan waktu untuk membagikan kajian keilmuan dan memberikan tugas serta dapat membuka ruang diskusi bagi para mahasiswa secara online. Namun demikian, terdapat syarat mutlak dalam mengaplikasikan Google Classroom yaitu membutuhkan akses internet (Nirfayanti \& Nurbaeti, 2019).

Sebagian besar peserta didik menilai pembelajaran menggunakan media online selama pandemi covid -19 sangat efektif. Mereka merasa memiliki semangat yang tinggi untuk belajar dan mengerjakan tugas selama penggunaan media online dalam pembelajaran daring (Mustakim, 2020). Sesuai dengan kajian empiris yang dilakukan (Pakpahan \& Fitriani, 2020) pemanfaatan teknologi informasi memiliki peranan yang sangat penting dalam pelaksanaan pembelajaran jarak jauh ditengah pandemi covid-19, proses 
p-ISSN : 2599-1418

e-ISSN : 2599-1426

pembelajaran bisa berjalan dengan baik adanya teknologi informasi yang sudah berkembang pesat saat ini serta jaringan internet yang dapat menghubungkan dosen dan mahasiswa sehingga proses belajar mengajar dapat berjalan dengan baik sebagai mana mestinya meskipun ditengah pandemi covid-19.

Efektivitas berkaitan dengan masalah bagaimana pencapaian tujuan atau hasil yang diperoleh, manfaat dari hasil yang diperoleh, tingkat daya fungsi unsur atau komponen serta masalah tingkat kepuasan penggguna (Hanafi \& Lubis, 2019). Terdapat beberapa indikator Efektifitas Pembelajaran yakni sebagai berikut: Terdapat pengorganisasian dengan baik, komunikasi antara pendidik dengan peserta didik dapat berjalanan secara aktif, menguasai materi yang diajarkan dan antusiasme dalam pembelajaran, Memiliki sikap positif terhadap peserta didik, memberi penghargaan dan penilaian yang adil pada peserta didik, secara aktif melibatkan peserta didik, membangkitkan motivasi peserta didik, menarik minat dan perhatian peserta didik, menggunakan media pembelajaran dan lebih luwes (Ekawat, 2017).

Menurut Setiawan \& IImiyah (2020) satu dampak pandemi corona virus 2019 yaitu terhadap dunia pendidikan di seluruh dunia, dimana seluruh pendidikan di Indonesia juga turut merasakan dampak tersebut berupa perubahan pelaksanaan pembelajaran dalam bentuk pembelajaran yang dilakukan dirumah maupun dengan sistem daring, menurut Rajab dalam Setiawan \& Ilmiyah, (2020) pandemi corona virus 19 menyebabkan halangan proses pendidikan satu hal yang dapat dilakukan adalah sistem pembelajaran jarak jauh dengan memanfaatkan teknologi yang ada. Karena jika tidak, maka pandemi ini akan merugikan kematangan hasil dan pencapaian proses pendidikan.

Technology Acceptance Model merupakan salah satu model untuk menganalisis dan memahami faktor diterimanya sebuah teknologi atau sistem. Model TAM merupakan salah satu model yang paling banyak digunakan dikarenakan model penelitian TAM sederhana dan mudah diterapkan (Suryawan \& Prihandoko, 2018). Cara perluasan TAM dengan menambahkan variabel eksternal ke dalam
Jurnal Pendidikan Ekonomi Undiksha

Vol. 13 No. 2 (2021)

model asli TAM seperti ditunjukkan berikut ini.

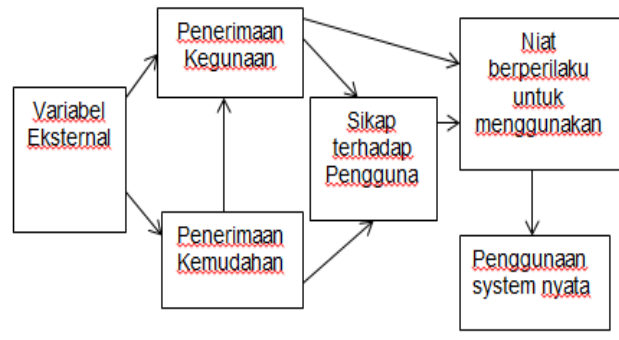

\section{Gambar 1.Teknology Acceptance Model dengan variabel Eksternal}

Pengaruh persepsi kegunaan terhadap penggunaan Google Classroom pada masa pandemi covid-19. I.N Sari (2019) persepsi kegunaan mempengaruhi dosen dan mahasiswa dalam menggunakan Google Classroom, menggunakan Google Classroom dapat meningkatkan produktivitas belajar dan mengajar bisadikatakan bahwa Google Classroom sangat efekif dalam proses perkuliahan.

$\mathrm{H}_{1}$ :Di duga persepsi kegunaan berpengaruh positif terhadap penggunaan Google Classroom pada masa pandemi covid-19.

Pengaruh persepsi kemudahan terhadap penggunaan Google Classroom pada masa pandemi covid-19. Saputra (2019) kemudahan penggunaan sebuah teknologi yang diterima oleh guru, maka semakin besar juga kesiapan guru didalam menggunakan sebuah teknologi. $\mathrm{H}_{2}$ : Diduga persepsi kemudahan berpengaruh positif terhadap penggunaan Google Classroom pada masa pandemi covid-19.

Pengaruh minat perilaku terhadap penggunaan Google Classroom pada masa pandemi covid-19. Saputra (2019) "semakin meningkat minat penggunaan sebuah teknologi yang diterima oleh guru, maka semakin besar juga kesiapan guru didalam menggunakan sebuah teknologi." $\mathrm{H}_{3}$ : Diduga minat perilaku berpengaruh positif terhadap penggunaan Google Classroom pada masa pandemi covid-19.

Pengaruh kualitas layanan terhadap penggunaan Google Classroom pada masa pandemi covid-19. Fariz Zhafiri (2018) setiap individu dalam menggunakan sebuah sistem 
p-ISSN : 2599-1418

e-ISSN : 2599-1426

tentunya memiliki persepsi dan keinginan atas penggunaan sistem tertentu.Kualitas pelayanan sebuah sistem dikatakan baik apabila sistem tersebut mampu untuk memenuhi harapan dari pengguna serta mampu dirasakan efektivitas ketika menggunakannya.

$\mathrm{H}_{4}$ : Diduga kualitas layanan berpengaruh positif terhadap penggunaan Google Classroom pada masa pandemi covid-19.

Pengaruh penggunaan Google Classroom pada masa pandemi covid-19 tehadap efeltivitas pembelajaran mahasiswa. I Suhada (2020) sesuai hasil pembelajaran daring berbasis Google Classroom pada mahasiswa pendidikan biologi pada masa wabah covid-19 hasilnya menyatakan penggunaan Google Classroom sudah cukup baik dan efektif, hanya saja akan lebih baik jika dipadukan dengan platform online lainnya.

$\mathrm{H}_{5}$ : Diduga penggunaan Google Classroom pada masa pandemi covid-19 berpengaruh positif terhadap efektivitas pembelajaran mahasiswa.

Pengaruh Tidak Langsung $\mathrm{H}_{6}$ : Diduga persepsi kegunaan berpengaruh positif terhadap efektivitas pembelajaran melalui penggunaan Google Classroom, $\mathrm{H}_{7}$ : Diduga persepsi kemudahan berpengaruh positif ngsung terhadap efektivitas pembelajaran melalui penggunaan Google Classroom, $\mathrm{H}_{8}$ : Diduga minat perilaku berpengaruh positif terhadap efektivitas pembelajaran melalui penggunaan Google Classroom, $\mathrm{H}_{9}$ : Diduga kualitas layanan berpengaruh positif terhadap efektivitas pembelajaran melalui penggunaan Google Classroom.

\section{METODE}

Populasi pada penelitian ini adalah mahasiwa Prodi Manajemen angkatan 2017/2018 sampai dengan angkatan 2019/2020 yang mengikuti perkuliahan pada semester Genap tahun akademik 2019/2020 berjumlah 305 mahasiswa. Dalam penelitian ini seluruh populasi dijadikan sampel dengan demikian penarikan sampel untuk responden dilakukan secara keseluruhan atau sampel jenuh. Teknik pengambilan sampel menggunakan metode sensus.Menurut Sugiono dalam (Hadi \&
Jurnal Pendidikan Ekonomi Undiksha

Vol. 13 No. 2 (2021)

Mahmudah, 2018) sampling jenuh merupakan teknik pengumpulan sampel dengan cara semua populasi yang ada dijadikan sampel.

Pada penelitian ini jenis data yang digunakan adalah kuantitatif. Penelitian ini menggunakan data primer, berupa pernyataan responden melalui koesioner dan wawancara dengan pihak - pihak yang berhubungan dengan penelitian yang dilakukan.Menurut Sugiono dalam (Hadi \& Mahmudah, 2018) data primer merupakan informasi yang diperoleh secara langsung dari tangan pertama oleh peneliti terkait dengan variabel ketertarikan untuk tujuan tertentu dari studi.

Penelitian ini pengumpulan datanya menggunakan kuesioner dan observasi. Sedangkan pengumpulan data kuesioner dengan cara disebarkan kepada responden melalui google form. Skala likert merupakan skala yang akan digunakan oleh peneliti dalam kuesioner.

Metode analisis deskriptif dengan pendekatan kuantitatif digunakan untuk mendapatkan gambaran secara sistematis, faktual dan akurat mengenai fakta-fakta, sifat-sifat serta hubungan mengenai indikator-indikator dalam variabel yang ada pada penelitian. Selanjutnya dilakukan uji asumsi klasik untuk mengetahui bahwa data layak untuk dilanjutkan uji regresi linier berganda.

Pengujian Hipotesis

Analisis regresi model I digunakan untuk mengetahui kekuatan hubungan dari Variabel Independen terhadap Variabel Dependen. Pada analisis regresi model I persamaan strukturalnya adalah: Efektivitas Pembelajaran Mahasiswa = b1 Penggunaan Google Classroom.

Analisis regresi model II digunakan untuk mengetahui kekuatan hubungan dari Variabel Independen terhadap Variabel Intervening. Pada analisis regresi model I persamaan strukturalnya adalah: Penggunaan Google Classrooom = b1 Persepsi kegunaan + b2 Persepsi Kemudahan + b3 Minat Pengguna + b4 Kualitas Layanan.

Analisis regresi model III digunakan untuk mengetahui kekuatan hubungan dari Variabel Variabel Dependen terhadap 
p-ISSN : 2599-1418

e-ISSN : 2599-1426

Variabel Interverning. Pada analisis regresi model III persamaan strukturalnya adalah: Efektivitas Pembelajaran Mahasiswa = b1 persepsi kegunaan $+b 2$ persepsi kemudahan + b3 minat pengguna + b4 Kualitas Layanan.

Uji koefisien determinasi (R2) merupakan alat yang digunakan dalam mengukur seberapa jauh kemampuan model dalam menjelaskan variabel dependen. Uji $F$ untuk melihat pengaruh variabel independen secara bersama-sama terhadap variabel dependen, jika angka probabilitas signifikasi kurang dari 0.05 maka variabel independen berpengaruh terhadap variabel independen secara bersama-sama, Uji Parsial (t) Guna melihat pengaruhantar variabel, peneliti membandingkan nilai t-hitung dari perhitungan dengan nilai t-tabel.
Jurnal Pendidikan Ekonomi Undiksha

Vol. 13 No. 2 (2021)

Metode pengujian hipotesis dalam penelitian ini menggunakan analisis regresi dengan metode analisis jalur (Path Analysis).Sugiono dalam (Hadi \& Mahmudah, 2018) "Variabel intervening (penghubung) merupakan variabel yang secara teoritis mempengaruhi hubungan antara variabel independen dan dependen menjadi hubungan yang tidak langsung dan tidak dapat diamati dan diukur. Variabel ini merupakan variabel penyela/antara yang terletak di antara variabel independen dan dependen, sehingga variabel independen tidak langsung mempengaruhi berubahnya atau timbulnya variabel dependen". Analisis jalur dalam penelitian ini untuk menguji pengaruh tidak langsung antara variabel independen dengan variabel dependen yang dimediasi oleh variabel.

\section{HASIL DAN PEMBAHASAN}

Tabel 1. Karakteristik responden berdasarkan jenis kelamin pada semester genap 2019/2020

Jenis Kelamin Jumlah Mahasiswa

Prosentase (\%)

\begin{tabular}{ccc}
\hline Laki-laki & 109 & $36,82 \%$ \\
\hline Perempuan & 187 & $63,18 \%$ \\
\hline Total & 296 & $100 \%$ \\
\hline
\end{tabular}

(Sumber : data primer penelitian 2020)

Berdasarkan data diatas, jumlah

jenis kelamin perempuan sejumlah 187 mahasiswa jenis kelamin laki - laki sejumlah 109 orang atau 36,82\% dan mahasiswa orang atau $63,18 \%$ dari keseluruhan.

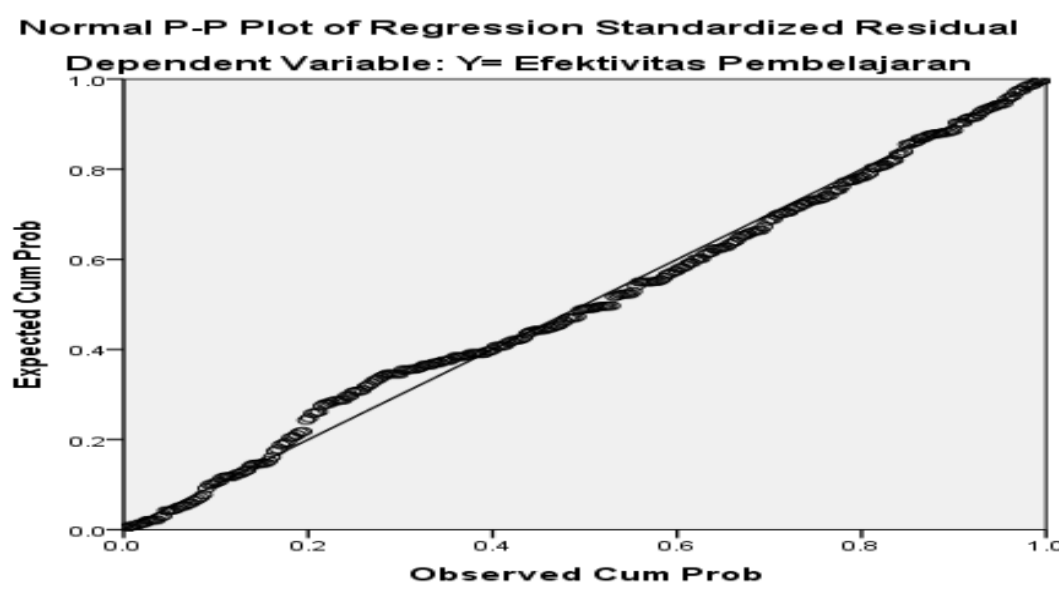

Gambar 2. Uji normalitas data

Hasil pengujian dengan menggunakan P-Plot pada gambar.2 menyatakan bahwa hasil penelitian berada menyebar disekitar garis diagonal dimana data mengikuti arah garis diagonal, dengan demikian hasilnya sudah terdistribusi normal dan regresi linier 
berganda pada penelitian ini memenuhi asumsi normalitas. Guna mendeteksi adanya multikolinearitas didalam model regresi, multikolinearitas dapat dilihat dari nilai toleran dan variance inflation factor
(VIF). Jika ada toleran lebih dari $10 \%$ atau VIF kurang dari maka dikatakan tidak ada multikolinearitas. Berikut ini merupakan tabel hasil uji multikolinearitas:

Tabel 2. Uji Multikolinearitas

\begin{tabular}{lrl}
\hline \multirow{2}{*}{ Model } & Collinearity Statistics & \\
\cline { 2 - 3 } & Tolerence & VIF \\
\hline Persepsi Kegunan & 0,994 & 1,060 \\
Persepsi Kemudahan & 0,720 & 1,389 \\
Minat Pengguna & 0,729 & 1,372 \\
Kualitas Layanan & 0,713 & 1,403 \\
\hline
\end{tabular}

(Sumber : data primer penelitian 2020)

Berdasarkan tabel di atas, dapat disimpulkan bahwa semua nilai VIF $<10$ dan nilai tolerance $>0,10$. Hal ini dapat diartikan bahwa tidak terjadi multikolinearitas sehingga uji multikolinearitas terpenuhi.

Scatterplot

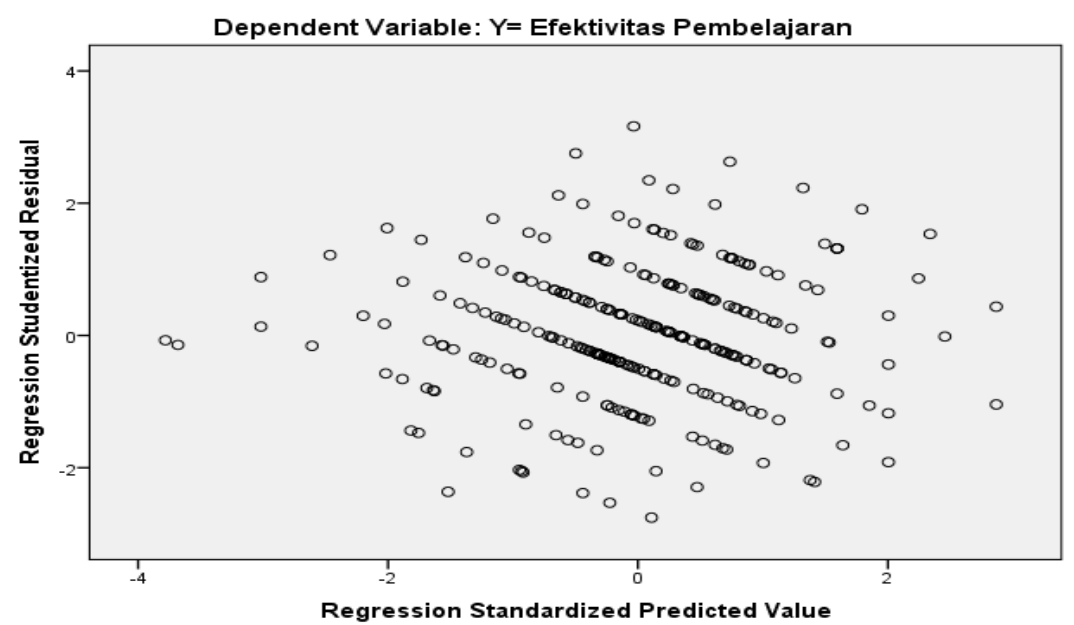

Gambar 3. Uji Heterokedastisitas

Berdasarkan gambar 1.diatasdapat diketahui bahwa titik-titik tidak membentuk pola yang jelas, tersebar dari kiri ke kanan dan sebagian ada yang mengelompok.Jadi

\section{Tabel 3.Uji Signifikansi Parameter Individual (uji t)}

\section{Coefficients $^{a}$}

\begin{tabular}{|c|c|c|c|c|c|c|}
\hline \multirow[t]{2}{*}{ Model } & & \multicolumn{2}{|c|}{$\begin{array}{c}\text { Unstandardized } \\
\text { Coefficients }\end{array}$} & \multirow{2}{*}{$\begin{array}{c}\text { Standardized } \\
\text { Coefficients } \\
\text { Beta } \\
\end{array}$} & \multirow[t]{2}{*}{$t$} & \multirow[t]{2}{*}{ Sig. } \\
\hline & & $\mathrm{B}$ & Std. Error & & & \\
\hline & (Constant) & 8.893 & .884 & & 10.064 & .000 \\
\hline 1 & $\begin{array}{l}\text { X=Penggunaan } \\
\text { Google } \\
\text { Classroom }\end{array}$ & .424 & .055 & .411 & 7.730 & .000 \\
\hline
\end{tabular}

a. Dependent Variable: $Y=$ Efektivitas Pembelajaran

(Sumber : Data primer penelitian,2020) 
Berdasarkan hasil uji pada tabel 8 diatas, maka didapat persamaan regresi dalam penelitian ini yaitu sebagai berikut : $\mathrm{Y}=8,893+0,411 \mathrm{X} 1+\mathrm{e}$

Berdasarkan hasil pengujian uji $t$ diperoleh hasil pengujian individual penggunaan Google Classroom menunjukan nilai $\mathrm{t}$ sebesar 7,730dengan

Tabel 4.Uji Signifikansi Parameter Individual (uji t)

\section{Coefficients $^{a}$}

\begin{tabular}{|c|c|c|c|c|c|c|}
\hline \multirow{2}{*}{\multicolumn{2}{|c|}{ Model }} & \multicolumn{2}{|c|}{$\begin{array}{l}\text { Unstandardized } \\
\text { Coefficients }\end{array}$} & \multirow{2}{*}{$\begin{array}{c}\text { Standardized } \\
\text { Coefficients } \\
\text { Beta }\end{array}$} & \multirow[t]{2}{*}{$\mathrm{t}$} & \multirow[t]{2}{*}{ Sig. } \\
\hline & & $B$ & Std. Error & & & \\
\hline \multirow{5}{*}{1} & (Constant) & 5.442 & 1.010 & & 5.391 & .000 \\
\hline & X1=Persepsi Kegunaan & .085 & .047 & .091 & 1.816 & .070 \\
\hline & $\begin{array}{l}\text { X2=Persepsi } \\
\text { Kemudahan }\end{array}$ & .187 & .049 & .221 & 3.846 & .000 \\
\hline & X3=Minat Pengguna & .204 & .054 & .215 & 3.751 & .000 \\
\hline & X4=Kualitas Layanan & .203 & .051 & .229 & 3.954 & .000 \\
\hline
\end{tabular}

a. Dependent Variable: $Y=$ Penggunaan Google Classroom

Berdasarkan hasil uji pada tabel 4 diatas, maka didapat persamaan regresi dalam penelitian ini yaitu sebagai berikut : $\mathrm{Y}=5,442+0,091 \mathrm{X} 1+0,221 \mathrm{X} 2+$ $0,215 \mathrm{X} 3+0,229 \mathrm{X} 4+\mathrm{e}(1)$

Berdasarkan hasil pengujian uji tpersepsi kegunaan menunjukan nilai $t$ sebesar 1,816 dengan signifikansi sebesar 0,07 jadi > 0,05, maka $\mathbf{H 1}$ tidakterdukung. Oleh karena itu, dapat diambil kesimpulan bahwa persepsi kegunaantidak berpengaruh positif signifikan terhadap penggunaan Google Classroom. Hasil pengujian individual persepsi kemudahan menunjukan nilai $t$ sebesar 3,846 dan juga signifikansi sebesar $0,00<0,05$, maka $\mathrm{H} 2$ terdukung. Oleh karena itu, dapat diambil kesimpulan signifikansi sebesar 0,00 jadi $<0,05$, maka H5 terdukung. Oleh karena itu, dapat diambil kesimpulan bahwa penggunaan Google Classroom berpengaruh positif signifikan terhadap efektivitas pembelajaran mahasiswa. bahwa persepsi kemudahan berpengaruh positif signifikan terhadap penggunaan Google Classroom. Hasil pengujian individual minat pengguna menunjukan nilai t sebesar 3.751dan juga signifikansi sebesar $0,00<0,05$, maka $\mathrm{H} 3$ terdukung. Oleh karena itu, dapat diambil kesimpulan bahwa minat pengguna Classroom berpengaruh positif signifikan terhadap penggunaan Google Classroom. Hasil pengujian individual kualitas layanan menunjukan nilai t sebesar 3,954 dan juga signifikansi sebesar $0,00<0,05$, maka H4terdukung. Oleh karena itu, dapat diambil kesimpulan bahwa kualitas layanan berpengaruh positif dan signifikan terhadap penggunaan GoogleClassroom.

Tabel 5. Hasil Uji Determinasi

\section{Model Summary}

\begin{tabular}{ccccc}
\hline Model & $\mathrm{R}$ & R Square & Adjusted R Square & $\begin{array}{c}\text { Std. Error of the } \\
\text { Estimate }\end{array}$ \\
\hline 1 & $.553^{\mathrm{a}}$ & .306 & .296 & 1.35745 \\
\hline
\end{tabular}

a. Predictors: (Constant), X4=Kualitas Layanan, X1=Persepsi Kegunaan, X3=Minat Pengguna, X2=Persepsi Kemudahan

(Sumber : data primer penelitian 2020)

Berdasarkan hasil uji determinasi (R2) diperoleh hasil sebesar 0,296 atau $29,6 \%$ maka seluruh variabel independen memiliki kontribusi pengaruh terhadap variable dependen sebesar $29,6 \%$ dan sisanya 
sebesar $70,4 \%$ dijelaskan variabel lain diluar model.

Tabel 6.Uji Signifikansi Parameter Individual (uji t)

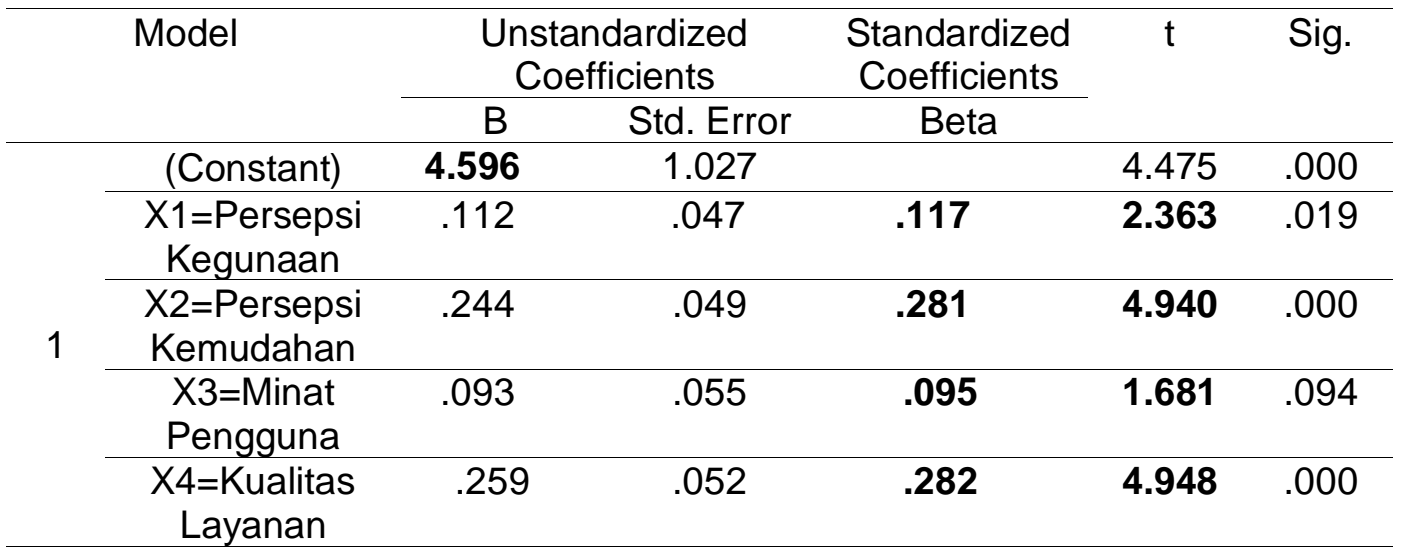

a. Dependent Variable: $Y=$ Efektivitas Pembelajaran

(Sumber : data primer penelitian 2020)

Berdasarkan hasil uji pada tabel 6 diatas, maka didapat persamaan regresi dalam penelitian ini yaitu sebagai berikut : $\mathrm{Y}=4,596+0,117 \times 1+0,281 \quad \mathrm{X} 2+0,095 \mathrm{X} 3+$ $0,282 \times 4+e$

Berdasarkan hasil pengujian uji tpersepsi kegunaan menunjukan nilai $t$ sebesar $\mathbf{2 . 3 6 3}$ dan dengan signifikansi sebesar 0,01 jadi < 0,05, maka $\mathrm{H} 1$ terdukung. Oleh karena itu, dapat diambil kesimpulan bahwa persepsi kegunaan berpengaruh positif signifikan terhadap penggunaan Efektivitas Pembelajaran. Hasil pengujian individual persepsi kemudahan menunjukan nilai $t$ sebesar 4.940 dan juga signifikansi sebesar $0,00<0,05$, maka H2 terdukung. Oleh karena itu, dapat diambil kesimpulan bahwa

Tabel 7.Uji Determinasi (R2)

Model Summary

\begin{tabular}{llll}
\hline Model & R Square $\quad$ Adjusted R Square & $\begin{array}{l}\text { Std. Error of the } \\
\text { Estimate }\end{array}$
\end{tabular}

$1 \quad .570^{\mathrm{a}} \quad 324 \quad .315 \quad 1.38095$

a. Predictors: (Constant), X4=Kualitas Layanan, X1=Persepsi Kegunaan, X3=Minat Pengguna, X2=Persepsi Kemudahan

(Sumber : Data primer penelitian,2020) 
p-ISSN : 2599-1418

e-ISSN : 2599-1426

Berdasarkan hasil uji determinasi (R2) diperoleh hasil sebesar 0,315 atau 31,5\% maka seluruh variabel independen memiliki kontribusi pengaruh terhadap variabel dependen sebesar $31,5 \%$ dan sisanya
Jurnal Pendidikan Ekonomi Undiksha

Vol. 13 No. 2 (2021)

sebesar $68,5 \%$ dijelaskan variabel lain diluar model.

Tabel 8.Uji Determinasi (R2)

Model Summary

\begin{tabular}{llrrr}
\hline Model & $\mathrm{R}$ & R Square & $\begin{array}{c}\text { Adjusted R } \\
\text { Square }\end{array}$ & $\begin{array}{c}\text { Std. Error of the } \\
\text { Estimate }\end{array}$ \\
\hline 1 & $.411^{\mathrm{a}}$ & .169 & .166 & 1.52379
\end{tabular}

a. Predictors: (Constant), X=Penggunaan Google Classroom

Berdasarkan hasil uji determinasi (R2) pada tabel 8 diperoleh hasil sebesar 0,166 atau 16,6 \% maka seluruh variabel independen memiliki kontribusi pengaruh terhadap variabel dependen sebesar 16,6 \% dan sisanya sebesar $84,4 \%$ dijelaskan variabel lain diluar model.

Pengaruh persepsi kegunaan Google Classroom terhadap penggunaan Google Classroom. X1 terhadap $Z=0,091$ Tidak terdukung, Pengaruh persepsi kemudahan Google Classroom terhadap penggunaan Google Classroom. X2 terhadap $\mathrm{Z}=$ 0,221 terdukung, Pengaruh minat pengguna Google Classroom terhadap penggunaan Google Classroom. X3 terhadap $Z=0,215$ terdukung, Pengaruh kualitas layanan Google Classroom terhadap efektivitas pembelajaran mahasiswa. X4 terhadap $Z=0,229$ terdukung.

Pengaruh persepsi kegunaan Google Classroom terhadap efektivitas pembelajaran mahasiswa. X1terhadapY= 0,117 terdukung, Pengaruh persepsi kemudahan Google Classroom terhadap efektivitas pembelajaran mahasiswa. X2 terhadapY $=0,281$ terdukung, Pengaruh minat pengguna Google Classroom terhadap efektivitas pembelajaran mahasiswa. $\mathrm{X} 3$ terhadap $\mathrm{Y}=0,095$ tidak terdukung, Pengaruh kualitas layanan Google Classroom terhadap efektivitas pembelajaran mahasiswa. X4 terhadapY $=0,282$ terdukung, Pengaruh penggunaan Google Classroom terhadap efektivitas pembelajaran mahasiswa. $Z$ terhadap $Y=0,411$ terdukung. 
0,117

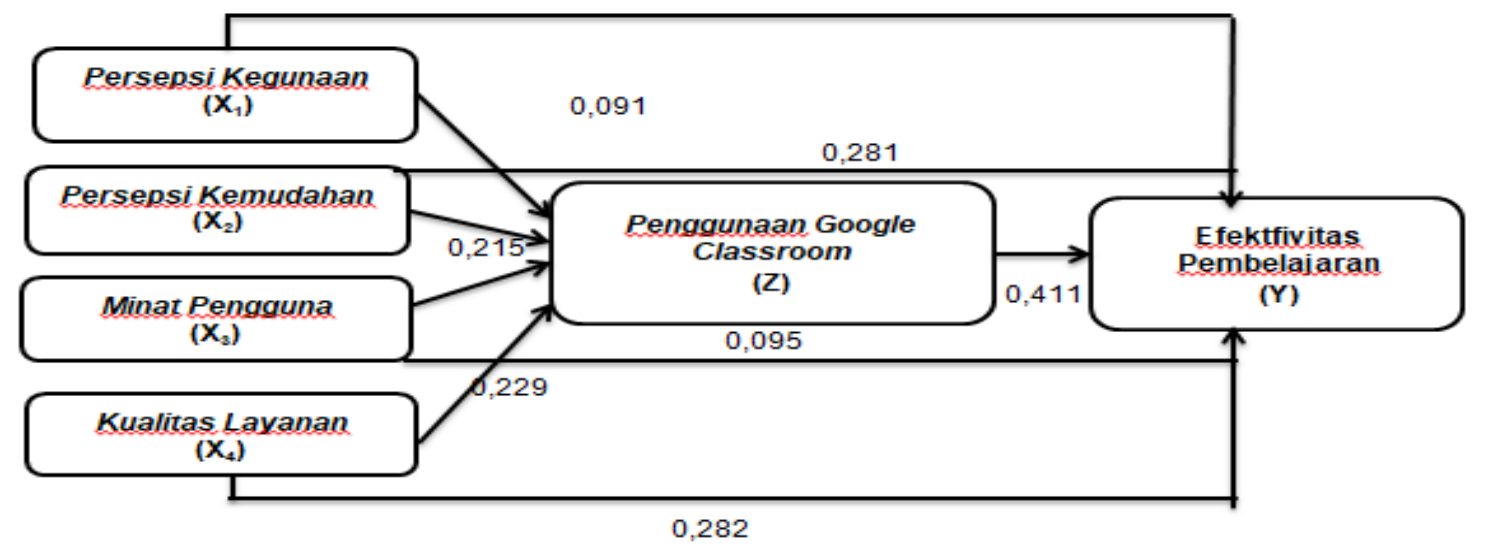

Gambar 4. Hasil Analisis Jalur

Tabel 9. Hasil Analisis Jalur dan Sobel Test

\begin{tabular}{ccccc}
\hline Model & $\mathrm{X} 1-\mathrm{Z}-\mathrm{Y}$ & $\mathrm{X} 2-\mathrm{Z}-\mathrm{Y}$ & $\mathrm{X} 3-\mathrm{Z}-\mathrm{Y}$ & $\mathrm{X} 4-\mathrm{Z}-\mathrm{Y}$ \\
\hline Pengaruh Langsung & 0,117 & 0,281 & 0,095 & 0,282 \\
\hline $\begin{array}{c}\text { Pengaruh Tidak } \\
\text { Langsung }\end{array}$ & $\begin{array}{c}0,091 \times 0,411 \\
=0.037\end{array}$ & $\begin{array}{c}0,221 \times \\
0,411 \\
=0,090\end{array}$ & $\begin{array}{c}0,215 \times 0,411 \\
=0,088\end{array}$ & $\begin{array}{c}0,229 \times \\
0,411 \\
=0,094\end{array}$ \\
\hline Pengaruh Total & 0,154 & 0,371 & 0,183 & 0,376 \\
\hline Sobel Test & 1,874 & 3,861 & 3,513 & 3,848 \\
\hline Z Score $\alpha=0,05$ & 1,96 & 1,96 & 1,96 & 1,96
\end{tabular}

(Sumber : Data Primer Penelitian 2020)

Berdasarkan hasil analisis pada tabel 4.diperoleh nilai $t$ sebesar 1,816 dengan signifikansi sebesar 0,07 jadi >0,05. Hal ini dapat diartikan bahwa persepsi kegunaan terhadap penggunaan Google Classroom tidak berpengaruh signifikan.Dengan demikian, hipotesis pertama yang menyatakan "Persepsi kegunaan Terhadap Penggunaan Google Classroom" Tidak Terdukung. Hal tersebut kemungkinan karena persepsi kegunaan tidak dapat memenuhi ekspektasi mahasiswa sehingga tidak berpengaruh terhadap keinginan menggunakan Google Classroom.

Pertama, mahasiswa merasa belum memaksimalkan Google Classroom sebagai alat untuk menunjang kegiatan proses belajar. Kedua, menurut mahasiswa fasilitas dari Google Classsroom tidak membantu menyelesaikan tugas menjadi cepat.Ketiga mahasiswa merasa dengan menggunakan
Google Classsroom efektivitas belajarnya tidak meningkat dan mereka merasa dengan menggunakan Google Classsroom masih belum mempermudah dalam mengerjakan tugas - tugas. Hasil penelitian ini tidak sejalan dengan kajian empiris yang dilakukan Sari (2019) dan Afrianti (2018) persepsi kemanfaatan berpengaruh positif terhadap penggunaan Google Classroom.

Berdasarkan hasil analisis pada tabel 4.diperoleh nilai nilai $t$ sebesar 3,846 dan juga signifikansi sebesar $0,00<0,05$. Hal ini dapat diartikan bahwa persepsi kemudahan terhadap penggunaan Google Classroom berpengaruh positif dan signifikan.Dengan demikian, hipotesis kedua yang menyatakan "Pengaruh persepsi kemudahanterhadap Penggunaan Google Classroom" Terdukung.

Menurut Rahman dan Dewantara dalam (Jundullah et al., 2019) "kemudahan 
p-ISSN : 2599-1418

e-ISSN : 2599-1426

pengunaan teknologi akan mengurangi usaha seseorang didalam mempelajari komputer.pengguna teknologi mempercayai bahwa teknologi yang lebih fleksibel, mudah dipahami dan mudah dioperasikan sebagai kemudahan penggunaan". Hasil analisis tersebut sejalan dengan uji empiris yang dilakukan Saputra (2019) yang menegaskan bahwa kemudahan penggunaan sebuah teknologi yang diterima oleh guru, maka semakin besar juga kesiapan guru didalam menggunakan sebuah teknologi. Kajian empiris ini juga sejalan dengan hasil penelitian Sari (2019) dan A Wijaya (2016) yang menemukan adanya pengaruh positif antara persepsi kemudahan terhadap penggunaan Google Classroom.

Berdasarkan hasil penelitian ini kemudahan Google Classroom dapat meningkatkan penggunaan Google Classroom pada mahasiswa pada Prodi Manajemen Fakultas Ekonomi Universitas Merdeka Pasuruan karena Google Classroom memberikan kemudahan mahasiswa dalam proses perkuliahan. Dosen dapat menyampaikan tugas, informasi, maupun dengan menggunakan Google Classroom mahasiswa dapat mengikuti perkuliahan dengan mudah meski tanpa harus datang kekampus.Selain itu mahasiswa juga dimudahkan untuk memperoleh informasi dan tugas - tugas yang diberikan oleh dosen secara cepat.

Berdasarkan hasil analisis pada tabel 4.diperoleh nilai $\mathrm{t}$ sebesar 3.751dan juga signifikansi sebesar $0,00<0,05$. Hal ini dapat diartikan bahwa minat pengguna terhadap penggunaan Google Classroom berpengaruh positif dan signifikan.Dengan demikian, hipotesis ketiga yang menyatakan "Pengaruh minat pengguna terhadap Penggunaan Google Classroom" Terdukung. A Rahman \& Dewantara (2017) menyatakan Minat perilaku merupakan suatu keinginan seseorang untuk melakukan suatu perlilaku tertentu. Seseorang akan melakukan perilaku jika memiliki keinginan untuk melakukannya.

Menggunakan Google Classroom membuat mahasiswa menjadi terbantu dalam pembelajaran pada saat terjadi pandemi covid-19 ini, setelah mengetahui kemudahan-kemudahan dalam
Jurnal Pendidikan Ekonomi Undiksha

Vol. 13 No. 2 (2021)

pembelajaran dengan menggunakan aplikasi Google Classroom mahasiswa antusias untuk menggunakan sarana aplikasi pembelajaran online lainya. Mahasiswa juga memotivasi orang lain supaya menggunakan Google Classroom karena sangat efektif dan membantu pada saat kuliah dengan model daring pada saat pandemi covid -19 .

Hasil penelitian ini sejalan dengan kajian empiris yang dilakukan Saputra (2019) "semakin meningkat minat penggunaan sebuah teknologi yang diterima oleh guru, maka semakin besar juga kesiapan guru didalam menggunakan sebuah teknologi. "Studi ini juga sejalan dengan penelitian yang dilakukan Sari (2019) Minat Pengguna terhadap Kegunaan Google Classroom berpengaruh positif dan signifikan.

Berdasarkan hasil analisis pada tabel 4.diperoleh $t$ sebesar 3,954 dan juga signifikansi sebesar $0,00<0,05$. Hal ini dapat diartikan bahwa kualitas layanan terhadap penggunaan Google Classroom berpengaruh positif dan signifikan. Dengan demikian, hipotesis keempat yang menyatakan "Pengaruh kualitas layanan terhadap Penggunaan Google Classroom" Terdukung. Mahasiswa merasa dengan menggunakan aplikasi Google Classroom tidak sulit ketika mengecek apakah tugas yang di kumpulkan telah terkirim, informasi yang tertera di Google Classroom mudah di pahami mahasiswa, sehingga memudahkan dalam menggunakanya.Mahasiswa merasa kegagalan sistem ketika menyelesaikan tugas dengan Google Classroom minim terjadi.

Hasil studi ini sesuai dengan penelitian yang dilakukan F Zhafiri (2018) setiap individu dalam menggunakan sebuah sistem tentunya memiliki persepsi dan keinginan atas penggunaan sistem tertentu. (F Zhafiri, 2018) Kualitas pelayanan sebuah sistem dikatakan baik apabila sistem tersebut mampu untuk memenuhi harapan dari pengguna serta mampu dirasakan efektivitas ketika menggunakanya. Penelitian ini juga didukung penelitian Sari (2019) dan Afrianti (2018) yang menegaskan bahwa kualitas layanan dari Google 
p-ISSN : 2599-1418

e-ISSN : 2599-1426

Classroom berdampak positif dan signifikan terhadap penggunaan Google Classroom.

Berdasarkan hasil analisis pada tabel 8.diperoleh nilai tsebesar 7,730 dengan signifikansi sebesar 0,00 jadi $<0,05$, . Hal ini dapat diartikan bahwa penggunaan Google Classroom terhadap efektivitas pembelajan berpengaruh positif dan signifikan. Dengan demikian, hipotesis kelima yang menyatakan "Pengaruh penggunaan Google Classroom terhadap efektivitas pembelajaran "Terdukung".

Studi ini sejalan dengan hasil peneltian Idad Suhada et al.,(2020) sesuai hasil pembelajaran daring berbasis Google Classroom pada mahasiswa pendidikan biologi pada masa wabah covid-19 hasilnya menyatakan penggunaan Google Classroom sudah cukup baik dan efektif, hanya saja akan lebih baik jika dipadukan dengan platform online lainnya. Kajian empiris ini juga sesuai dengan penelitian Sari (2019) yang menyatakan Penggunaan Google Classroom berpengaru positif dan signifikan terhadap Efektivitas Pembelajaran.

Berdasarkan penelitian

ini penggunaan Google Classroom pada masa pandemi covid - 19 dapat meningkatkan efektivitas pembelajaran mahasiswa pada prodi Manajemen Fakultas Ekonomi Universitas Merdeka Pasuruan. Penggunaan Google Classroom mampu membuat mahasiswa lebih cepat dalam berkomunikasi dengan dosen pengampu selain itu lebih cepat dalam memberikan dan menerima informasi tanpa harus bertatap muka dikelas. Selain itu dengan menggunakan Google Classroom mahasiswa merasa termotivasi menyelesaikan tugas melalui Google Classroom karena ada tenggang waktu yang di berikan dosen maka dengan menggunakan Google Classroom proses pembelajaran menjadi semakin efektif dan kedepan jika pandemi covid -19 ini berakhir penggunaan Google Classroom bisa diterapkan dalam pengggunaan flatform pembelajaran online di prodi manajemen.

Berdasarkan hasil analisis data pada penelitian ini Persepsi Kegunaan berpengaruh secara langsung terhadap efektivitas pembelajaran mahasiswa sedang
Jurnal Pendidikan Ekonomi Undiksha

Vol. 13 No. 2 (2021)

pengaruh Persepsi Kegunaan terhadap efektivitas pembelajaran mahasiswa melalui Penggunaan Google Classroom tidak memberikan pengaruh. Persepsi kegunaan tidak berpengaruh secara signifikan dalam meningkatkan efektivitas belajar mahasiswa diduga karena penggunaan Google Classroom belum memberikan kemudahan mahasiswa dalam mengerjakan tugas dan diduga mahasiswa masih belum menguasai penggunaan Google Classroom karena flatform pembelajaran digital dengan berbantu Google Classroom baru pertama diterapkan di prodi manajemen Fakutas Ekonomi Universitas Merdeka Pasuruan.

Oleh sebab itu dalam pencapaian efektivitas pembelajaran yang lebih baik dalam penggunaan Google Classroom tanpa melibatkan persepsi kegunaan karena persepsi kegunaan dari Google Classroom tidak memberikan dampak dalam pencapainan efektivitas pembelajaran mahasiswa.Hasil analisis penelitian ini tidak sejalan dengan kajian empiris yang dilakukan Sari (2019) yang menyatakan bahwa penggunaan Google Classroom berperan sebagai quasi mediation hubungan antara kegunaan Google Classroom dan efektivitas pembelajaran mahasiswa.

Hasil uji empiris penelitian ini menemukan bahwa Pengaruh Persepsi Kemudahan terhadap Efektivitas Pembelajaran Mahasiswa melalui Penggunaan Google Classroom terdukung. Persepsi kemudahan Google Classroom mampu meningkatkan efektivitas pembelajaran mahasiswa hal ini ditunjukkan dari Google Classroom, pengumuman, materi kuliah, tugas kuliah, maupun pengumpulan tugas kuliah menjadi lebih fleksibel sehingga mampu meningkatkan efektivitas pembelajaran. Hasil kajian empiris ini sejalan dengan penelitian Sari (2019) yang menyatakan bahwa penggunaan Google Classroom berperan sebagai quasi mediation hubungan antara kegunaan Google Classroom dan efektivitas pembelajaran mahasiswa. Didukung hasil penelitian Jundullah et al., (2019) penggunaan sistem e-learning mampu meningkatkan kepuasan mahasiswa.

Hasil uji empiris penelitian ini menemukan bahwa Pengaruh minat 
p-ISSN : 2599-1418

e-ISSN : 2599-1426

pengguna terhadap Efektivitas Pembelajaran Mahasiswa melalui Penggunaan Google Classroom terdukung. Menurut M.R Gaffar \& Septyandi (2020) Semakin Pengguna E-Learning Puas, maka Pengguna akan cenderung untuk memilih menggunakan E-Learning sebagai media pembelajaran di masa yang akan datang.

Mahasiswa prodi Manajemen Fakultas Ekonomi Universitas Merdeka Pasuruan dengan menggunakan Google Classroom berminat menambah aplikasi lain untuk meningkatkan pemahaman tentang sarana pembelajaran daring, mereka terbantu dalam pembelajaran dengan adanya Google Classroom, mahasiswa memotivasi dan mendukung orang lain untuk menggunakan Google Classroom karena mereka merasa dengan menggunakan Google Classroom karena sangat membantu dan memberikan kemudahan dalam aktivitas daring di masa pandemi covid -19 ini. Efektivitas Pembelajaran menjadi meningkat di prodi manajemen dengan menggunakan aplikasi Google Classroom karena didukung minat pengguna yaitu mahasiswa terbantu dengan menggunakan aplikasi Google Classroom. Hasil penelitian ini sesuai dengan penelitian Afrianti (2018) dan Sari (2019).

Hasil uji empiris penelitian ini menemukan bahwa Pengaruh Kualitas Layanan terhadap Efektivitas Pembelajaran Mahasiswa melalui Penggunaan Google Classroom terdukung. Menurut Mohammad Rizal Gaffar \& Septyandi (2020) Semakin Pengguna E-Learning Puas, maka Pengguna akan cenderung untuk memilih menggunakan E-Learning sebagai media pembelajran di masa yang akan datang.

Berdasarkan hasil penelitian ini kualitas layanan Google Classroom sangat memberikan dampak positif dalam meningkatkan efektivitas pembelajaran pada prodi Manajemen Fakultas Ekonomi hal ini dapat dirasakan mahasiswa karena mahasiswa mampu mengerjakan dan mengumpulkan tugas dengan cepat dan mudah, mahasiswa menjadi lebih faham dalam menerapkan penggunakan teknologi dalam pembelajaran serta dengan menggunakan Google Classroom mereka mampu dengan cepat mendapatkan
Jurnal Pendidikan Ekonomi Undiksha

Vol. 13 No. 2 (2021)

informasi dari dosen terkait materi pembelajaran.

Menurut R Utami (2019) Kualitas sistem dan layanan adalah sistem yang menghasilkan informasi yang akurat dan efisien serta memberikan layanan yang dibutuhkan oleh pengguna. kualitas layanaan tidak hanya meliputi ketika terjadinya proses pembelajaran, namun juga meliputi bagaimana perkiraan subjektif pengguna terhadap dosen sebagai penyelenggara kelas Google Classroom apabila terjadi gangguan pada saat penggunaan. F Zhafiri (2018) Penggunaan sebuah sistem setiap individu tentunya memiliki persepsi dan keinginan atas penggunaan sistem tertentu.Kualitas pelayanan sebuah sistem dikatakan baik apabila sistem tersebut harus mampu untuk memenuhi harapan dari pengguna dan mampu dirasakan efektivitas ketika menggunakannya.

\section{SIMPULAN DAN SARAN}

Pengaruh Persepsi Kegunaan terhadap Penggunaan Google Classroom Berdasarkan hasil penelitian persepsi kegunaan tidak berpengaruh positif dan signifikan terhadap penggunaan Google Classroom Persepsi kegunaan Terhadap Penggunaan Google Classroom Tidak Terdukung, Pengaruh Persepsi Kemudahan terhadap Penggunaan Google Classroom Berdasarkan hasil penelitian persepsi kemudahan berpengaruh positif dan signifikan terhadap penggunaan Google Classroom Persepsi kemudahan terhadap Penggunaan Google Classroom Terdukung.

Pengaruh Minat Pengguna terhadap Penggunaan Google Classroom Berdasarkan hasil penelitian minat pengguna berpengaruh positif dan signifikan terhadap penggunaan Google Classroom, minat pengguna terhadap Penggunaan Google ClassroomTerdukung Pengaruh Kualitas Layanan terhadap Penggunaan Google Classroom Berdasarkan hasil penelitian kualitas layanan berpengaruh positif dan signifikan terhadap penggunaan Google Classroom, kualitas layanan terhadap Penggunaan Google Classroom Terdukung. 
p-ISSN : 2599-1418

e-ISSN : 2599-1426
Jurnal Pendidikan Ekonomi Undiksha

Vol. 13 No. 2 (2021)
Pengaruh Penggunaann Google
Classroom terhadap Efektivitas

Pembelajaran Berdasarkan hasil penelitian penggunaan Google Classroom berpengaruh positif dan signifikan terhadap efektivitas pembelajaran, Google Classroom terhadap Efektivitas Pembelajaran Terdukung. Pengaruh Persepsi Kegunaan terhadap Efektivitas Pembelajaran melalui Penggunaan Google Classroom. Persepsi kegunaan tidak berpengaruh secara signifikan dalam meningkatkan efektivitas belajar mahasiswa diduga karena penggunaan Google Classroom belum memberikan kemudahan mahasiswa dalam mengerjakan tugas dan diduga mahasiswa masih belum menguasai penggunaan Google Classroom karena flatform pembelajaran digital dengan berbantu Google Classroom baru pertama diterapkan di prodi manajemen Fakutas Ekonomi Universitas Merdeka Pasuruan.

Pengaruh Persepsi Kemudahan terhadap Efektivitas Pembelajaran melalui Penggunaan Google Classroom.

Pengaruh Persepsi Kemudahan terhadap Efektivitas Pembelajaran Mahasiswa melalui Penggunaan Google Classroom terdukung.Persepsi kemudahan Google Classroom mampu meningkatkan efektivitas pembelajaran mahasiswa hal ini ditunjukkan dari Google Classroom, pengumuman, materi kuliah, tugas kuliah, maupun pengumpulan tugas kuliah menjadi lebih fleksibel sehingga mampu meningkatkan efektivitas pembelajaran. Pengaruh Minat Pengguna terhadap Efektivitas Pembelajaran melalui Penggunaan Google Classroom Pengaruh minat pengguna terhadap Efektivitas Pembelajaran Mahasiswa melalui Penggunaan Google Classroom terdukung. Efektivitas Pembelajaran menjadi meningkat di prodi manajemen dengan menggunakan aplikasi Google Classroom karena didukung minat pengguna yaitu mahasiswa terbantu dengan menggunakan aplikasi Google Classroom.

Pengaruh Kualitas Layanan terhadap Efektivitas Pembelajaran melalui Penggunaan Google Classroom Pengaruh Kualitas Layanan terhadap Efektivitas Pembelajaran Mahasiswa melalui
Penggunaan Google Classroom terdukung. kualitas layanan Google Classroom sangat memberikan dampak positif dalam meningkatkan efektivitas pembelajaran pada prodi Manajemen Fakultas Ekonomi hal ini dapat dirasakan mahasiswa karena mahasiswa mampu mengerjakan dan mengumpulkan tugas dengan cepat dan mudah, mahasiswa menjadi lebih faham dalam menerapkan penggunakan teknologi dalam pembelajaran serta dengan menggunakan Google Classroom mereka mampu dengan cepat mendapatkan informasi dari dosen terkait materi pembelajaran.

\section{DAFTAR PUSTAKA}

Afrianti, W. . (2018). Penerapan Google Classroom Dalam Pembelajaran Akuntansi (Studi Pada Program Studi Akuntansi Universitas Islam Indonesia) [Universitas Islam Indonesia Yogyakarta].

https://dspace.uii.ac.id/handle/1234567 89/6173.

Ekawat, T. (2017). Pengaruh Kompetensi Profesional Guru Palembang. Universitas Islam Negeri.

Gaffar, M.R, \& Septyandi, C. . (2020). Usinge-Learning Media During The Corona Faktor Yang Mempengaruhi Kepuasan Mahasiswa Dalam Menggunakan Media E-Learning Selama Periode Pandemik Corona. $8(1)$.

Gaffar, Mohammad Rizal, \& Septyandi, C. B. (2020). USINGE-LEARNING MEDIA DURING THE CORONA FAKTOR YANG MEMENGARUHI KEPUASAN MAHASISWA $D A L A M$ MENGGUNAKAN MEDIA ELEARNING SELAMA PERIODE PANDEMIK CORONA. 8(1).

Hadi, N., \& Mahmudah, U. (2018). Pengaruh Kualitas Pelayanan Perpajakan Terhadap Kepatuhan Wajib Pajak. AKTSAR: Jurnal Akuntansi Syariah, 1(2), 257. https://doi.org/10.21043/aktsar.v1i2.52 22

Hanafi, \& Lubis. (2019). Analisis Perspektif Global Guru Pengaruhnya. 7(4), 289293. 
Jundullah, M., Umar, R., \& Yudhana, A. (2019). Analisis Penerimaan Sistem ELearning SMK Negeri 4 Kota Sorong Dengan Menggunakan Technology Acceptance Model (TAM). Prosiding Semnastek.

Mustakim. (2020). Efektivitas Pembelajaran Daring Menggunakan Media Online Selama Pandemi Covid-19 Pada Mata Pelajaran Matematika The Effectiveness of E-Learning Using Online Media During The Covid-19 Pandemic in Mathematics. 2(1), 1-12.

Nirfayanti, N., \& Nurbaeti, N. (2019). Pengaruh Media Pembelajaran Google Classroom Dalam Pembelajaran Analisis Real Terhadap Motivasi Belajar Mahasiswa. Proximal, 2(1), 5059.

https://doi.org/https://doi.org/10.30605/ 2615-7667.211

Pakpahan, R., \& Fitriani, Y. (2020). Analisa Pemanfaatan Teknologi Informasi dalam Pembelajaran Jarak Jauh di Tengah Pandemi Virus Corona Covid19. Journal of Information System, Applied, Management, Accounting and Research, 4(2), 30-36.

Rahman, A., \& Deantara, R. . (2017). Pengaruh Kemudahan Penggunaan dan Kemanfaatan Teknologi Informasi Terhadap Minat Menggunakan Situs Jual Beli Online. Jurnal Administrasi Bisnis, 52(1), 1-7. administrasibisnis.studentjournal.ub.ac .id\%0A

Saputra, M. . (2019). Analisis Faktor-Faktor Yang Mempengaruhi Kesiapan Guru Dalam Menggunakan E-Learning Moodle Dengan Menggunakan Teori Technology Acceptance Model (TAM) (Studi Kasus Guru SMK Aceh Besar). https://repository.arraniry.ac.id/id/eprint/11007

Sari, I. . (2019). Terhadap Efektivitas Pembelajaran Mahasiswa Universitas Islam Indonesia [Universitas Islam Indonesia Yogyakarta]. https://dspace.uii.ac.id/bitstream/handl e/123456789/13733/isna normalita sari.pdf?sequence $=1$ \&isAllowed $=y$

Setiawan, A. R., \& Ilmiyah, S. (2020). Lembar Kegiatan Siswa Untuk
Pembelajaran Jarak Jauh Berdasarkan Literasi Saintifik Pada Topik Penyakit Coronavirus 2019 (COVID-19).

Suhada, I. (2020). Pembelajaran Daring Berbasis Google Classroom Mahasiswa Pendidikan Biologi Pada Masa Wabah Covid-19. Digilib.Uinsgd.Ac.ld, 1-9.

Suhada, Idad, Kurniati, T., Pramadi, A., Listiawati, M., Biologi, P. P., Gunung, S., \& Bandung, D. (2020). Pembelajaran Daring Berbasis Google Classroom Mahasiswa Pendidikan Biologi Pada Masa Wabah Covid-19. Digilib.Uinsgd.Ac.Id, 1-9.

Suryawan, M. ., \& Prihandoko, P. (2018). Evaluasi Penerapan SIAKAD Politeknik Negeri Madiun Menggunakan Pendekatan TAM dan EUCS. Creative Information Technology Journal, 4(3), 233.

https://doi.org/10.24076/citec.2017v4i3 .113

Syarifudin, A. S. (2020). Impelementasi Pembelajaran Daring Untuk Meningkatkan Mutu Pendidikan Sebagai Dampak Diterapkannya Social Distancing. Jurnal Pendidikan Bahasa Dan Sastra Indonesia Metalingua, 5(1), 31-34.

https://doi.org/10.21107/metalingua.v5i 1.7072

Utami, R. (2019). Analisis Respon Mahasiswa Terhadap Penggunaan Google Classroom Pada Mata Kuliah Psikologis Pembelajaran Matematika. Prisma, Prosiding Seminar Nasional Matematika, 2, 498-502.

Utami, Rini. (2019). Analisis Respon Mahasiswa terhadap Penggunaan Google Classroom pada Mata Kuliah Psikologi Pembelajaran Matematika. Prisma, Prosiding Seminar Nasional Matematika, 2, 498-502.

Wijaya, A. (2016). Analysis of Factors Affecting the Use of Google Classroom to Support Lectures. International Conference on Information Technology and Engineering Application, 5(1), 6168.

Windarti, Z. \& G. I. K. \& A. (2020). Impact of Corona Virus Outbreak Towards Teaching and Learning Activities in 
p-ISSN : 2599-1418

e-ISSN : 2599-1426

Indonesia. SALAM; Jurnal Sosial \& Budaya Syar-IALAM; Jurnal Sosial \& Budaya Syar-I, 7(3), 269-282. https://doi.org/10.1017/CBO97811074 15324.004

Zhafiri, F. (2018). Pengaruh Persepsi Manfaat, Persepsi Kemudahan,
Jurnal Pendidikan Ekonomi Undiksha

Vol. 13 No. 2 (2021)

Persepsi Risiko dan Kualitas Layanan Penggunaan Terhadap Keinginan Untuk Menggunakan Electronic Money dengan Sikap Sebagai Variabel Intervening (Studi Kasus: Penerapan Electronic Money di Stasiun Pengisian $B$. 